\title{
КУЛЬТУРНО-ЦИВИЛИЗАЦИОННЫЕ КОНФЛИКТЫ В СОВРЕМЕННОЙ МИРОВОЙ ПОЛИТИКЕ: ДИАЛОГ ИЛИ СТОЛКНОВЕНИЕ?
}

\begin{abstract}
Аннотация: Настоящая статья посвящена исследованию структуры, особенностей и специфики современных международных конфликтов, возникающих на почве столкновения мировых циивлизаций и тех иенностей, которые они несут формирующемуся многополярному миру. Объектом исследования выступают международные конфликты, предметом - иивилизационный фактор, определяющий характер взаимодействия сторон, особенности эволюичи конфликта, ценностный антагонизм, специфику механизмов конфликтной мобилизации и особенности настройки конфликта и всех его участников на поиск формуль мирного урегулирования (разрешения). При этом особое внимание уделяется уточнению понятия «цивилизация» в сфере конфликтного взаимодействия, выявлению причин антагонизма изивилизачий, порождающих иивилизационные разломы, столкновения (скрытые или открытые) или различные формы длительного противостояния. Методология исследования включает в себя системный, структурно-функииональный и культурно-цивилизационный подходы, методы сравнительно-исторического, сравнительно-политического и ретроспективного анализа. Результаты исследования заключаются в том, что современные межиивилизационные конфликты развиваются по мультивариантным сценариям: взаимодействие цивилизаций может порождать как столкновение, так и различные формы диалога или даже партнерства. Гипотеза столкновения цивилизаций, выдвинутая С. Хантингтоном, в этом контексте не может рассматриваться как полноценная научная теория, хотя она и дает некоторое интуитивное (не доказанное) понимание важности иивилизационного фактора в современных международных конфликтах, а таккже в их урегулировании, разрешении и управлении ими.

Abstract: This article is dedicated to the research on the details of the structure and specifics of modern international conflicts, which emerge on the grounds of clashes between world's civilizations and the values that they bring into the forming multipolar world. Object of this research is the international conflicts; the subject of it is the civilizational factor, which defines the nature of the relations between the sides, aspects of the evolution of the conflict, axiological antagonism, specificity of the mechanisms of conflict mobilization, and steering the conflict and all its participants towards finding a way of a peaceful resolution. Some of the methods used in this research are: structural-functional and culturo-civilizational approaches, historico-comparative, politico-comparative, and retrospective analysis. The result of the research shows that modern civilizational conflicts can develop in multiple scenarios: relations between civilizations can result in a conflict, or various forms of dialogue and even partnership.
\end{abstract}

Ключевые слова: Политика, право, международные отночения, конфликт, иивилизация, культура, управление конфликтами, разрешение конфликтов, конфликтная мобилизация, безопасность.

Keywords: Politics, law, international relations, conflict, civilization, culture, conflict management conflict resolution, conflict mobilization, security.

овременный мир переживает эпоху глобальных изменений. Современная политическая действительность «все больше определяется глобальной политической нестабильностью, в которую мир перешел в результате эрозии Вестфальской системы. На фоне ее распада и хаотизации международных отноше- ний происходит формирование нового миропорядка, основанного на принципах многополярности»‥ При

\footnotetext{
${ }^{1}$ Будаев A.B. Роль «мягкой силы» во внешней политике России (на примере российско-бразильских отношений): Автореф. дисс. ... канд. полит. наук. М.: ДА МИД РФ, 2014.
} 


\section{Право и политика 11 (179) • 2014}

этом система международных отношений становится все более анархичной ${ }^{2}$. Наблюдается нарастающий кризис идеи «демократического мира»- стержневого концепта эпохи однополярности ${ }^{3}$.

Темпы и скорость глобальных изменений непрерывно растут: всего один год потребовался западным политтехнологам для того, чтобы превратить спокойную и процветающую Северную Африку, некоторые страны которой (например, Тунис) по уровню жизни практически ни чем не отличались от южных департаментов Франции, в очаг жесточайшей гражданской войны, международного терроризма и радикального исламизма. Теперь такая же участь ждет Сирию, а вместе с ней и весь Ближний Восток, включая главного непримиримого оппонента США - Иран.

Создается впечатление, что сегодня эрозии подвергаются сами основы Вестфальской системы, разрушаются платформы и механизмы, которые на протяжении многих десятилетий служили делу поддержания мира и политической стабильности, сохранению баланса между различными силами и группам интересов в глобальной политике. Сегодня все это стремительно распадается на отдельные фрагменты под натиском правового нигилизма, двойной морали и «управляемого хаоса» ${ }^{4}$. В образовавшийся вакуум стремятся проникнуть силы, которые долгое время выступали идейными противниками демократического мира с его универсальными общечеловеческими ценностями: политические экстремисты и радикалы, террористы, исламисты всех мастей, националисты и, наконец, на примере Украины - неофашисты.

В своём стремлении снизить конфликтный потенциал современного мира политики и ученые используют все возможности для предотвращения межцивилизационных столкновений, порождающих глобальные конфликты и кризисы. Однако, «во все времена и эпохи конфликты неизбежны как внутри обществ, так и между ними. Сегодня и практики и теоретики приходят к пониманию того, что бесконфликтное общество - это утопия, не существует

\footnotetext{
${ }^{2}$ Wendt A. Anarchy is What States Make of It: the Social Construction of Power Politics // International Organization. Vol. 46. № 2. Spring 1992. P. 391-425.

${ }^{3}$ Цыганков А.П., Цыганков П.А. Кризис идеи «демократического мира» // Международные процессы. 2005. № 3.

${ }^{4}$ Andrei Manoilo. "Revoluciones de los higos", elemento enfurecido o «caos controlado»? // Vida Internacional. Digest. 2011. pp. 148-162
}

бесконфликтных отношений. Для конфликтов всегда имеется множество оснований» ${ }^{5}$.

Понимание специфики современного международного конфликта служит снижению конфликтного потенциала современности. Как отмечает исследователь Н. И. Леонов: «Конфликт стал реальностью нашей жизни. Более того, наступил этап, когда в общественном сознании произошли изменения и отношение к конфликту стало не только как к естественному, но в некоторых случаях даже как к желательному явлению. Это порождает проблему эффективного управления конфликтом во всех областях его проявления. Многие авторы считают, что решение этой проблемы становится настолько очевидным, что, либо XXI век станет веком конфликтологии (как науки о конфликтах), либо он будет последним в истории цивилизации» ${ }^{6}$. Поэтому сегодня, как и ранее, учёные всего мира должны опираться на достижения мировой научной и философской мысли, которая накопила достаточный интеллектуальный багаж знаний о конфликтах. Анализ и осмысление работ мыслителей прошлого и современности должен дать теоретическую базу для недопущения или разрешения многочисленных конфликтов, которые можно отнести к цивилизационным. Таким образом, не только для конфликтологов, но и представителей других наук, изучение опыта конфликторазрешения становится актуальной задачей, не теряющей своей новизны в настоящее время.

В общей теории конфликтов столкновения цивилизаций занимают особое место. С одной стороны, социокультурные образования слишком сложны для рассмотрения их в качестве элементарного или упрощённого образования, выступающего субъектом конфликта. С другой стороны, проистекающей из первой качественной характеристики, противоборство цивилизаций имеет глобальный масштаб и значительное количество участников.

При исследовании структуры конфликта цивилизаций, обнаруживаются стороны, которые оказывают многофакторное воздействие на столкновение, но их влияние настолько амбивалентно, что возникают трудности с оценкой их роли в конфликте. Таким образом, столкновения цивилизаций сложноструктурированное для качественного и количественного анализа явление,

\footnotetext{
${ }^{5}$ Абгаджава Д. А., Филатова Н. В. О возможностях регулирования социально-политических конфликтов // Гуманитарные исследования, 2007. № 4. С. 17-19.

${ }^{6}$ Леонов Н. И. Онтологическая сущность конфликта // Хрестоматия по конфликтологии. - М., 2003. С. 268
} 
поэтому их место является исключительным в теоретических построениях и, тем более, практических решениях по прекращению конфликтов.

Как было указано ранее, концепцию столкновения цивилизаций внёс в научную, а затем и практическую повестку дня американский политолог С. Хантингтон. Его обращение к проблеме было вызвано сменой парадигм в теории противостояния с идеологического (утратившего силу), на новую модель, сохраняющую, тем не менее, свой конфликтный потенциал. Объясняя отмену конфронтационной модели и поиск новой политолог Ф. Петито писал: «Сложившиеся к завершению «холодной войны» биполярные оппозиции, стратегически организованные вокруг сфер влияния и управляемые посредством общего языка реалистичной этики государственной мудрости, вызвали, кроме всего прочего, обширные дебаты по поводу будущего мировой политики и обусловили необходимость в коренном пересмотре моральных устоев, на основе которых должна будет строиться новая модель международного сосуществования» 7.

С окончанием холодной войны (главной детерминантой которой выступала идеология) идеологическое противостояние было объявлено завершённым. Это давало уверенность в победе одной, следовательно, наиболее стойкой идеологии - либерализма. Известный политолог Ф. Фукуяма так заявлял (хотя и преждевременно) о процессах того времени: «Триумф Запада, западной идеи очевиден прежде всего потому, что у либерализма не осталось никаких жизнеспособных альтернатив. В последнее десятилетие изменилась интеллектуальная атмосфера крупнейших коммунистических стран, в них начались важные реформы. Этот феномен выходит за рамки высокой политики, его можно наблюдать и в широком распространении западной потребительской культуры, в самых разнообразных её видах... То, чему мы, вероятно, свидетели, - не просто конец холодной войны или очередного периода послевоенной истории, но конец истории как таковой, завершение идеологической эволюции человечества и универсализации западной либеральной демократии как окончательной формы правления» ${ }^{8}$.

Тем не менее, его победное наступление либерализма не состоялось. Существовали препятствия для принятия американских либеральных ценностей, в том числе странами Запада, объявленного победителем в

\footnotetext{
${ }^{7}$ Столкновение или диалог цивилизаций // http://glasru.ru/ stolknovenie-ili-dialog-tsivilizatsiy/

${ }^{8}$ Фукуяма Ф. Конец Истории? // США: экономика, политика, идеология. 1990. № 5. С. 39-54.
}

холодной войне. Необходимо было другое основание для продолжения активных наступательных действий в условиях глобализации. Взамен и была предложена идея о перманентном столкновении цивилизаций.

Концепция столкновения цивилизаций несла в себе ряд практических моментов. Во-первых, она позволяла вновь консолидировать страны Запада под единой (цивилизационной) эгидой. Ведь с исчезновением второго полюса биполярной системы, исчез образ сильного и агрессивного врага. Многие государства, политика которых определялась в годы холодной войны «советской угрозой», вернулись к внешнеполитической линии определяемой версальско-вашингтонской системой. По сути - это означало зарождение раскола второго полюса на независимые структуры. Такая ситуация делала некогда объединившийся в противостоянии СССР и социалистическим странам блок неподконтрольным укрепившимся мировым гегемонам. Цивилизационная парадигма выполняла задачу обратной консолидации этих стран.

Во-вторых, концепция столкновения цивилизаций определяла новые угрозы для консолидированного Запада. Взамен бывшего СССР, С. Хантингтон указал на две цивилизации - исламскую и китайскую, выраженные объединённым религиозными основами (в данном случае арабский мир и другие мусульманские государства) и коммунистический Китай (что также определяло угрозу для некоммунистического Запада).

В-третьих, идея о том, что цивилизации непрерывно сталкиваются, то есть, по сути, конфликтуют друг с другом, выступала легитимизирующей основой для самих агрессии со стороны западного мира. Впервые озвученная А. Дж. Тойнби в качестве не абсолютной, идея о перманентном конфликтном столкновении культурных сообществ ${ }^{9}$, была преобразована американским политологом в основную для последующего практического использования во внешней политике. Опираясь на данную теоретическую модель, Запад оказывался не только участником столкновений (наряду с другими цивилизациями), но и закреплял право вмешиваться в подобные процессы между другими социокультурными образованиями. Хотя сам автор концепции предостерегал Запад от вмешательства в дела других, тем не менее, модель включала механизмы активного воздействия и вторжения в иные цивилизации.

Сам С. Хантингтон считает, что цивилизация есть «наивысшая культурная общность людей и самый широкий уровень культурной идентификации, помимо

\footnotetext{
${ }^{9}$ См. Тойнби А. Цивилизация перед судом истории. - М., 2006.
} 
DOI: $10.7256 / 1811-9018.2014 .11 .12937$

При цитировании этой статьи сноска на доі обязательна

\section{Право и политика $11(179) \cdot 2014$}

того, что отличает человека от других биологических видов. Она определяется как общими объективными элементами, такими как язык, история, религия, обычаи, социальные институты, так и субъективной самоидентификацией людей» ${ }^{10}$. Однако, в этих рассуждениях скрывается некоторый элемент неопределённости, связанный с понятием идентичности и идентификации. Необходимо раскрыть данный аспект для дальнейшего понимания сути конфликтных процессов между цивилизациями.

Человеческим сообществам, так же как и отдельному индивиду свойственны процессы идентификации с теми или иными социальными образованиями или иными проявлениями общественного бытия. Начинаясь на личностном уровне, идентификация проходит ряд ступеней от низшего к высшим, включая в себя более масштабные объекты. Для пояснения данного тезиса Хантингтон приводит такой таксономический ряд идентичности: «Есть несколько уровней идентификации людей: житель Рима может ощущать себя в различной степени римлянином, итальянцем, католиком, христианином, европейцем и жителем Запада. Цивилизация, к которой он принадлежит, является самым высоким уровнем, который помогает ему четко идентифицировать себя» ${ }^{11}$. В приведённом ряду существует несколько идентичностей, с которыми отождествляет себя один человек. Это порождает специфическую проблему субъективности ощущений и отождествления для индивида. В одной социокультурной общности могут существовать многие основания для идентификации, которые, порождая внутри неё социальные границы, служат базисом для конфликтов. Сама природа идентичности предполагает деление на бинарную оппозицию «Я/ Мы-Он/Они». Эта схема определяет в сознании образ «Другого» ${ }^{12}$ не всегда обладающего нейтральными или приемлемыми характеристиками. Тем самым, в радикальном выражении «Другой» обретает черты «Чужого», с приписываемыми ему атрибутами.

Отношение к «Чужому» также может быть диверсифицировано от нейтрального до агрессивно-враждебного, что, в свою очередь, выступает психологическим основанием для конфликта. Как было указано ранее, причисление себя к той или иной группе, ведёт к идентификации с данной группой. В условиях конфликта

\footnotetext{
${ }^{10}$ Хантингтон С. Столкновение цивилизаций. - М., 2005. С. 51.

${ }^{11}$ Там же.

${ }^{12}$ См. Нойманн И. Использование «Другого»: Образы Востока в формировании европейских идентичностей. - М., 2004.
}

такое отождествление способствует распространению на данную группу установок на конфликтное поведение и вовлечению в него индивида. Учитывая тот факт, что «Чужой» является противоположной стороной в актуализированном конфликте и по отношению к нему допустимы все действия, которые ведут к победе над ним.

Таким образом, субъективное отождествление себя с той или иной социальной общностью или социокультурным образованием (цивилизацией) выступает основанием для конфликта. Факт субъективности принадлежности является весомым, но чаще всего игнорируемым личностью, что даёт возможность отождествлять себя с любыми, в том числе нереальными общностями. Можно определить цивилизационный конфликт как конфликт идентичностей, в данном случае, идентичностей высшего порядка. При этом, наивысшая культурная идентичность - цивилизация, содержит в себе идентичности низшего уровня, которые могут выступать фактором раскола или распада цивилизации в силу их неоднозначной природы. Их дифференциация может включать основания, противоречащие цивилизационной идентичности. Исследователи И. Кондаков, К. Соколов и Н. Хренов приводят такую иерархию идентичностей:

1. Аскриптивные - возраст, пол, кровное родство, этническая и расовая принадлежность.

2. Культурные - клановая, племенная, языковая, национальная, религиозная, цивилизационная принадлежность.

3. Территориальные - ближайшее окружение, деревня, город, провинция, штат, регион, климатическая зона, континент, полушарие.

4. Политические - фракционная и партийная (в широком смысле - от клики до общественного движения) принадлежность, преданность лидеру, группы интересов, идеология, интересы государства.

5. Экономические - работа, профессия, должность, рабочее окружение, наниматели, отрасли, экономические секторы, профсоюзы, классы, государства.

6. Социальные - друзья, клубы, команды, коллеги, компании для развлечений, социальный статус ${ }^{13}$.

Как видно из приведённой классификации, цивилизационная идентичность может уступать место и зачастую уступает низшим идентичностям. Отсюда можно сделать вывод о существовании не одного, а нескольких видов конфликтов, в котором одной стороной неизбежно выступает цивилизация.

\footnotetext{
13 Цивилизационная идентичность в переходную эпоху: культурологический, социологический и искусствоведческий аспекты / Кондаков И. В., Соколов К. Б., Хренов Н. А. - М., 2011. С. 43-44.
} 
Первым видом следует назвать прямые цивилизационные конфликты, то есть столкновения цивилизаций. Под ними понимают конфликты разнообразной интенсивности и локализации, происходящие между субъектами, принадлежащими различным цивилизациям. В целом, можно определить, что эти конфликты происходят на границах цивилизаций, к которым примыкают иные цивилизации. Тем самым, конфликты обретают вид региональных или межгосударственных детерминируемых цивилизационными различиями субъектов. С точки зрения конфликтологии эти конфликты можно соотнести с классическими схемами, что облегчает задачу их типологизации и квалификации. Исходя из понимания сути подобных конфликтов, их анализ также может быть произведён с использованием широко применимых методов, что, в свою очередь позволяет разрешать конфликты с применением распространённого инструментария.

Однако, сам С. Хантингтон отмечал, что границы цивилизаций обозначаются весьма условны. Это ведёт к тому, что локализация конфликтов может быть затруднена, а часть из них может происходить внутри пространств цивилизаций. Таким образом, наивысшая культурная идентичность внутри одной цивилизации может принадлежать другой цивилизации. В силу смешивания национальностей, культур, других атрибутов, определяющих ту или иную идентичность, процессы их образования внутри нетождественных цивилизаций происходят постоянно и повсеместно. Примеры есть в большинстве из перечисленных Хантингтоном цивилизаций. Подтверждением этому может служить китайская цивилизация, которая включает в себя Синьцзян-Уйгурский автономный район (исламская идентичность) и Тибет (индо-буддистская цивилизационная идентичность). Таким образом, природа цивилизационных конфликтов детерминирована включённостью в пространство цивилизаций инородных элементов.

Другим фактором, воздействующим на возникновение цивилизационных конфликтов, выступает случаи нарушения цивилизационной идентичности и противоречия, связанные с данной проблемой. Хантингтон, называет две цивилизации, которые подпадают под эту схему. Это латиноамериканская, обладающая двойственной цивилизационной идентичностью, и африканская (потенциальная), не имеющая собственной идентичности и не выработавшая её.

В первом случае, конфликт цивилизаций может быть в ней самой, как столкновение двух противоречащих друг другу идентичностей, таких как западная и индо-американская. Хантингтон отмечает «жители Латинской Америки отличаются по субъективной самоидентификации. Некоторые говорят: «Да, мы - часть Запада». Другие заявляют: «Нет, у нас своя уникальная культура» ${ }^{14}$

Во втором случае, любая сила, способная направить тенденции по формировании идентичностей в нужное для себя русло, способна обеспечить отождествление африканских народов со своей культурой. Напомним, что Северная и часть Восточной Африки принадлежат исламской цивилизации, Южная Африка - западной. Таким образом, Мезоафрика или Субсахарская Африка, станет потенциальной ареной борьбы за конструирование цивилизационной идентичности между двумя крупными цивилизациями на пространстве несформированной третьей.

К конфликтам связанным с цивилизационным отождествлением следует отнести и случаи столкновения самих цивилизаций с меньшими идентичностями, включёнными в высшие. Данные идентичности способны выступать как основа для конфликта даже в случаях схожих базовых установок их определяющих. Таковым, например, можно отнести существующее в исламском мире разделение на шиитов и суннитов, достаточно негативно относящихся друг к другу. Ещё одно течение в исламе - салафизм, также позиционируется как враждебное к двум, указанным выше. Таким образом, ислам представляет собой не единую религиозную идентичность, а конфессионально разнородную структуру, которую нельзя назвать гомогенной цивилизацией. То, что данные течения ислама могут быть враждебно настроены по отношению к иным, свидетельствуют события XIX-XXI столетий, наглядно демонстрирующих столкновения внутри мусульманского мира.

Важным аспектом концепции столкновения цивилизаций является то, что Хантингон обозначает две противоборствующих полюса системы - Запад и неЗапад. Именно цивилизации, которые могут выступать в качестве субъектов международного конфликта, так же могут быть большими общностями, поддерживающими конфликт в других общностях, внутри иных цивилизаций. В некоторых случаях цивилизации могут быть стороной конфликта в отношении собственных внутренних идентичностей. В силу того факта, что одним из субъектов выступает цивилизация, такой конфликт также может быть отнесён к цивилизационным.

Природа цивилизационных конфликтов достаточно сложна, но их проявление наблюдаемо и может быть

\footnotetext{
${ }^{14}$ Хантингтон С. Столкновение цивилизаций. - М., 2005. С. 57.
} 
DOI: $10.7256 / 1811-9018.2014 .11 .12937$

При цитировании этой статьи сноска на dоі обязательна

\section{Право и политика $11(179) \cdot 2014$}

зафиксировано для анализа и отчасти для разрешения наборов методов и инструментарием конфликтологов. Такую сторону данных конфликтов отмечает и разработчик модели столкновения цивилизаций. Он, в частности, отмечает «чаще всего конфликты между странами и группами, принадлежащими к различным цивилизациям, разгораются из-за обычных причин: контроль над населением, территорией, богатствами и ресурсами, а также относительного могущества, то есть возможность насадить собственные ценности, культуру и институты в другой группе по сравнению с возможностью другой группы сделать то же самое с вами» ${ }^{15}$.

В целом, именно глубинные причины цивилизационного конфликта отличают его от «простых» региональных, локальных или социальных конфликтов, которые в свою очередь могут и не иметь цивилизационного «основания». Тем самым, ставится проблема вычленения цивилизационного компонента в различных конфликтах, что принципиально для его разрешения или возможного предотвращения. Ведь в случае цивилизационного противостояния силы сторон оказываются в ситуации поддержки значительных культурных и религиозных образований, препятствующему наиболее рациональному способу разрешения конфликтов. То есть, за участниками всегда будут находиться мощные акторы (цивилизации), заинтересованные в конфликте и победе в нём. Это определяет структуру и динамику конфликтов.

Как отмечает А.В. Манойло «современные конфликты непрерывно вырабатывают новые формы конфликтного взаимодействия, более социально-опасные, но, вместе с тем и более управляемые. В эволюции международных конфликтов возникла новая фаза - межцивилизационная. В этой фазе консолидация сил, средств и ресурсов его участников строится по принципу принадлежности к определенной культуре или цивилизации, продвигающей свою систему ценностей, что позволяет объединять и мобилизовывать намного более значительные людские и материальные ресурсы, а статус локальных конфликтов поднимать до уровня межцивилизационного противостояния. Концепция столкновения цивилизаций - это механизм мобилизации ресурсов нового поколения: он превосходит возможности национально-государственной идеологии, способной для участия в конфликте мобилизовать (по национальному признаку) ресурсы одного государства и его политических союзников. В конфликтах нового поколения мобилизация ресурсов идет на ментальном, ценностном уровне, объединяющем

${ }^{15}$ Хантингтон С. Столкновение цивилизаций. - М., 2005. С. 192 трансграничные и многонациональные массы людей, принадлежащих к общей цивилизационной парадигме или культурной традиции»» ${ }^{16}$.

Исходя из качественно новых параметров цивилизационных конфликтов, отметим ряд важных элементов в их структуре ${ }^{17}$. В строении указанных конфликтов присутствуют такие специфические черты как конфликт ценностей, конфликт интересов и конфликт смыслов, которые зачастую имеют культурное или религиозное содержание, что в свою очередь детерминируется цивилизационными характеристиками. Под конфликтом ценностей понимают - отношения между социальными группами, исповедующими несовместимые ценности. Типичными для такого рода конфликтов являются межконфессиональная вражда и политическое противостояние ${ }^{18}$. Именно такая составная цивилизационного конфликта сопровождает столкновение различных групп внутри или вовне социальных образований. Для того, чтобы конфликт ценностей перешёл политические границы, необходимо участие государства, что ещё более закрепляет идентичность и способствует усилению конфликтогенного потенциала и увеличению степени насилия, так как данный политический институт обладает вооружёнными силами.

Другой стороной противостояния на цивилизационном уровне выступает конфликт интересов основанный на столкновении интересов различных социальных субъектов или отношений ${ }^{19}$. Как и в случае конфликта ценностей, конфликт интересов также требует привлечения ресурсов, в том числе политических. Это увеличивает потенциал одного или нескольких субъектов конфликтного взаимодействия, а в случае цивилизаций - привлекает на сторону участников значительные силы.

Наиболее сложным в ситуационном анализе является конфликт смыслов. Под ним понимают «противоречия во внутреннем понимании идей, целей или содержания чего-либо» ${ }^{20}$. Важным для понима-

\footnotetext{
${ }^{16}$ Манойло А. В. Ценностные основы управления межцивилизационными конфликтами // http://mir-politika.ru/334-upravlenie konflictami.html

${ }^{17}$ Манойло А.В. Модель информационно-психологической операции в международных конфликтах. // Право и политика. -2008 . - №6. - С.1387-1394.

${ }^{18}$ Белов В. И. Классификация конфликтов // http://www.sociology. mephi.ru/docs/sociologia/html/belov_conflicts.html

${ }_{19}$ Аниупов А. Я, Шипилов А. И. Словарь конфликтолога. - СПб., 2006. C. 165

${ }^{20}$ Шепталова Е. Г. Психология конфликта // http://www.personalpsychology.ua/Sheptalova/articles/357/sense.html
} 
ния данного вида конфликтов является тот факт, что смыслы выступают субъективным по отношению к окружающему миру ментальным образованием, которое не всегда поддаётся качественному анализу, что, зачастую, делает недоступным его понимание.

Примером конфликта смыслов можно назвать разное отношение к смыслу истории как конечной цели существования цивилизаций. Так «в западном понимании смыслом истории является так называемый прогресс, как развитие от дикости к высотам духовности, от бытовой грязи к гигиене и другим благам цивилизации. Причем данная модель развития, не отвергая духовную природу и потребности человека, признает также и его свободу. Понимание смысла истории в Исламе сильно отличается от понимания западного. С точки зрения мусульманской интеллектуальной традиции, которая развивалась стараниями многих поколений богословов, история, увы, представляет собой непрерывный регресс. Например, Золотой век, когда жил эталон человеческой личности - Пророк Мухаммад, сменился эпохой идейной смуты и еретических расколов» ${ }^{21}$.

Таким образом, векторы развития истории, определяемые закладываемыми в них смыслами, выступают разнонаправленными друг по отношению к другу. Далее такое понимание ведёт к тому, что цели двух миров просто не совпадают, а стремление навязать или восстановить желаемое состояние ведёт к полномасштабному цивилизационному конфликту и его негативным последствиям.

Также, важным обстоятельством конфликта смыслов выступает тот аспект, что однозначное понимание идей или целей определено различными факторами. Зачастую они оказывают длительное культурно-историческое, религиозное и иное воздействие, тем самым ещё более закрепляя содержание смыслов, делая их мене пластичными и, зачастую, просто неспособными к трансформациям.

Подходя к завершению анализа специфики цивилизационных конфликтов, следует отметить важный фактор, который выступает одним из основополагающих в инициировании всех типов подобных противостояний. Это геополитический фактор, который определяется глобальным масштабом самих цивилизационных образований и стремлением расширить пространство собственной цивилизации ${ }^{22}$, что в условиях «закрытого» мира неизбежно ведёт к столкновениям.

Геополитический фактор определяет функции государств, как элементов в системе цивилизаций, в отношении географической среды. По сути - это и есть та среда, в которой происходят цивилизационные конфликты. Цивилизации, а точнее государства внутри них, используют весь арсенал средств для пространственного расширения. Сами цивилизационные структуры обладают «центр-периферическим» строением, в котором окраины выступают как проводники культуры и религии вовне и активные участники (инициаторы) конфликтов.

Само стремление к территориальным приобретениям, каковы бы ни были избранные для этого инструменты, провоцирует сопротивление со стороны контрагента. Итогом подобных действий становится межцивилизационный конфликт, осложнённый участие вооружённых сил, информационно-психологической агрессией, экономическими, политическими и иными мерами. Цивилизации в условиях глобализирующегося мира находятся в состоянии соприкосновения друг с другом, а инфокоммуникационные технологии сжимают географическое пространство. Неслучайно современный конфликт цивилизаций всё чаще обретает вид информационной войны на разрушение ценностей, смыслов и переформатирование интересов. Лидером подобных процессов сегодня, как и много веков подряд, выступает западная цивилизация.

Некоторые цивилизации отвечают асимметричными мерами, часто используя терроризм как метод сопротивления, усиливая, тем самым, перманентный конфликт. Другие сопротивляются натиску, с той или иной степенью успеха, расходуя ресурсы не на развитие, а на продолжающееся противостояние. Отказ от сопротивления вызывает ситуацию геополитического сжатия $^{23}$, что чревато не только для цивилизационной идентичности, но и идентичностей низшего уровня, за которым последует неизбежной поглощение. Можно с уверенностью утверждать, что концепция столкновения цивилизаций стала решающей в поддержании конфликтного потенциала в глобальном масштабе. Подобные коллизии ведут к нарастающим угрозам не только отдельным культурам или нациям, но и всему человечеству в целом.

\footnotetext{
${ }^{21}$ Столкновение Запада и Востока. Конфликт пониманий смыслов историй // http://islam-today.ru/obsestvo/stolknovenie_zapada_i_ vostoka_konflikt_ponimanij_smyslov_istorij/

${ }^{22}$ См.: Киселёв С. Г. Основной инстинкт цивилизаций и геополитические вызовы России. - М., 2002.
}
${ }^{23}$ См.: Комлева Н. А. Геополитическое сжатие // Мировая эконо- мика и международные отношения. 2003. № 2. С. 66-75


DOI: $10.7256 / 1811-9018.2014 .11 .12937$

При цитировании этой статьи сноска на dоі обязательна

\section{Право и политика $11(179) \cdot 2014$}

Библиография:

1. Анцупов А. Я, Шипилов А. И. Словарь конфликтолога. СПб: Питер, 2006. - 517 с.

2. Бродель Ф. Грамматика цивилизаций. - М.: Издательство «Весь мир», 2008. - 552 с.

3. Бродель Ф. Материальная цивилизация, экономика и капитализм. XV-XVIII вв. Т. 1. Структуры повседневности. Возможное и невозможное. - М.: Издательство «Весь мир», 2007. -592 с.

4. Бродель Ф. Материальная цивилизация, экономика и капитализм. XV-XVIII вв. Т. 2. Игры обмена. - М.: Издательство «Весь мир», 2006. - 672 с.

5. Бродель Ф. Материальная цивилизация, экономика и капитализм. XV-XVIII вв. Т. 3. Время мира. - М.: Издательство «Весь мир», 2007. - 752 с.

6. Геродот. История. - М.: АСТ: АСТ МОСКВА, 2006. - 696 с.

7. Данилевский Н. Я. Россия и Европа. - М.: Книга, 1991. - 574 с.

8. Ежегодник СИПРИ 2011: вооружения, разоружение и международная безопасность. - М.: ИМЭМО РАН, $2012 .-768$ с.

9. Иноземцев В. Л. Расколотая цивилизация. - М.: Наука, Академия, 1999. - 704 с.

10. Киселёв С. Г. Основной инстинкт цивилизаций и геополитические вызовы России. - М.: Известия, $2002 .-368$ с.

11. Кузык Б. Н., Яковец Ю. В. Цивилизации: теория, история, диалог, будущее. В 2-х т. Т. 1. Теория и история цивилизаций. - М.: Институт экономических стратегий, 2006. - 768 с.

12. Кузык Б. Н., Яковец Ю. В. Цивилизации: теория, история, диалог, будущее. В 2-х т. Т. 2. Будущее цивилизаций и геоцивилизационные измерения. - М.: Институт экономических стратегий, 2006. - 648 с.

13. Мак-Нил У. Восхождение Запада. История человеческого сообщества. - М.: Ника-центр, Старклайт, 2004. - 1064 с.

14. Манойло А. В. Технологии несилового разрешения современных конфликтов. / Под ред. проф. А.И. Петренко. - М.: Горячая линия - Телеком, 2008. - 392 с.

15. Морган Л. Г. Древнее общество или Исследование линий человеческого прогресса от дикости через варварство к цивилизации. - Л.: Изд-во ин-та народов Севера ЦИК СССР, 1935. - 350 с.

16. Леонтьев К. Н. Славянофильство и грядущие судьбы России. - М.: Институт русской цивилизации, 2010. - 1232 с.

17. Полибий. Всеобщая история. В 2 томах. Том 1. Книги I-X. - М.: ООО «Издательство АСТ», 2004. - 765 с.

18. Полибий. Всеобщая история. В 2 томах. Том 2. Книги ХІ-ХХІХ. - М.: ООО «Издательство АСТ», $2004 .-765$ с.

19. Нойманн И. Использование «Другого»: Образы Востока в формировании европейских идентичностей. - М., Диалог, 2004. $-316 \mathrm{c}$.

20. Руссо Ж. - Ж. Трактаты. - М.: Наука, 1969. - 703 с.

21. Andrei Manoilo. "Revoluciones de los higos", elemento enfurecido o «caos controlado»? // Vida Internacional. Digest. 2011. pp. 148-162

22. Манойло А.В. Национально-государственные модели психологического управления конфликтами. // ОбозревательObserver. - 2008. - №2. - C.118-123.

23. Религия и общество. Хрестоматия по социологии религии. Под ред. Гараджа В. И., Руткевич Е. Д. - М., Наука, 1994. - 469 с.

24. Сорокин П. А. Социальная и культурная динамика. - М.: АСТ, Астрель, 2006. - 1176 с.

25. Старобинский Ж. Поэзия и знание. История литературы и культуры. - М.: Языки славянской культуры, $2002 .-496$ с.

26. Тойнби А. Дж. Постижение истории - М.: Прогресс, 1991. - 736 с.

27. Тойнби А. Цивилизация перед судом истории. - М.: Айрис-Пресс.

28. Февр Л. Бои за историю. - М.: Наука, 1991. - 629 с.

29. Фукидид. История. Том І. - СПб.: Пролог, Наука, 1994. - 403 с.

30. Фукидид. История. Том II. - СПб.: Пролог, Наука, 1994. - 445 с.

31. Чаадаев П. Я. Избранные сочинения и письма. - М., Правда, 1991. -560 с.

32. Хантингтон С. Столкновение цивилизаций. - М.: АСТ, 2005. -576 с.

33. Цивилизации. Выпуск 2 // Сост.: М. Барг. - М.: Наука, 1993. - 238 с.

34. Цивилизационная идентичность в переходную эпоху: культурологический, социологический и искусствоведческий аспекты / Кондаков И. В., Соколов К. Б., Хренов Н. А. - М.: Прогресс, 2011. - 434 с.

35. Шпенглер О. Закат Европы. Очерки морфологии мировой истории. В 2-х т. Т. 1. Гештальт и действительность. - М.: Мысль, 1998. - 663 с.

36. Авксентьев В. А., Аксюмов Б. А., Хоц А. Ю. Конфликт цивилизаций: PRO ET CONRA // Социологические исследования 2000, № 3. С. 73-81

37. Абгаджава Д. А., Филатова Н. В. О возможностях регулирования социально-политических конфликтов // Гуманитарные исследования, 2007. № 4. С. 17-19

38. Авксентьев В. А., Аксюмов Б. В. «Конфликт цивилизаций» в региональном преломлении: Кавказ и Балканы // Полис (Политические исследования). 2007. № 4. - С. 146-157.

39. Комлева Н. А. Геополитическое сжатие // Мировая экономика и международные отношения. 2003. № 2. С. 66-75Фукуяма Ф. Конец истории?// США: экономика, политика, идеология. 1990. № 5. С. 39-54.

40. Трифонов С. С. Конструирование идентичности как геополитическая технология // Современные проблемы социо-гуманитарного знания // Материалы XVI Международной конференции «Балтийский форум», 4-6 декабря 2013 г. / Под ред. Ивашкин Н., Антонов Б., Пешеходина А., СПб., Изд-во СПбГУТ им. Бонч-Бруевича, 2013. - 212 с. 
41. Белов В. И. Классификация конфликтов // http://www.sociology.mephi.ru/docs/sociologia/html/belov_conflicts.html

42. Манойло А. Несиловое регулирование международных конфликтов. Культурно-цивилизационные парадигмы // http://www.perspektivy.info/book/nesilovoje_regulirovanije_mezhdunarodnyh_konfliktov_kulturno-civilizacionnyje_ paradigmy 2009-03-30.htm

43. Манойло А. Политические конфликты в международных отношениях и мировой политике // http://mir-politika.ru/3999politicheskie-konflikty-v-mezhdunarodnyh-otnosheniyah-i-mirovoy-politike.html

44. Столкновение Запада и Востока. Конфликт пониманий смыслов историй // http://islam-today.ru/obsestvo/stolknovenie_ zapada_i_vostoka_konflikt_ponimanij_smyslov_istorij

45. Шепталова Е. Г. Психология конфликта // http://www.personalpsychology.ua/Sheptalova/articles/357/sense.html

46. Ferguson A. An Essay on the History of Civil Society // http://oll.libertyfund.org/title/1428

47. Манойло А.В. Модель информационно-психологической операции в международных конфликтах. // Право и политика. - 2008. - №6. - C.1387-1394.

48. Репьева А.М. Нациестроительство. Формирование и сущностные характеристики (США и Россия).// NB: Международные отношения. 2013. № 2. С. 68-79.

49. О. Г. Карпович Сравнительный анализ форматов моделей и технологий управления международными конфликтами США и ЕС и современных миротворческих операций // Национальная безопасность / nota bene. - 2011. - 6. - C. 138-149.

50. О. Г. Карпович Миротворческая деятельность США и англосаксонские технологии управления международными конфликтами // Национальная безопасность / nota bene. - 2012. - 1. - C. 64-74.

51. И. В. Бочарников Северо-Кавказский регион: проблемы и перспективы реализации государственной политики России // Международные отношения. - 2012. - 1. - С. 36-45.

52. А. В. Манойло Парадигмы управления международным конфликтами: конкуренция или конфронтация // Национальная безопасность / nota bene. - 2011. - 5. - С. 135-142.

53. Петренко А.И. Сирийский гамбит // Международные отношения. - 2013. - 1. - C. 92-95. DOI: 10.7256/2305-560X.2013.01.11.

54. Гушер А.И. Геополитическая картина современного мира // Международные отношения. - 2013. - 1. - C. 13-21. DOI: 10.7256/2305-560Х.2013.01.2.

55. А. В. Манойло Актуальные вопросы модернизации современной культурно-цивилизационной теории управления международными конфликтами // Национальная безопасность / nota bene. - 2011. - 4. - C. 60-66.

56. Карпович О.Г.. Новый миропорядок и конфигурирование системы международных отношений во внешней политике США // Политика и Общество. - 2013. - № 10. - C. 104-107. DOI: 10.7256/1812-8696.2013.10.10013

57. Карпович О.Г.. Проблемы и перспективы исследования современных концепций, моделей и технологий управления международными конфликтами // Национальная безопасность / nota bene. - 2013. - № 5. - C. 104-107. DOI: 10.7256/20738560.2013.5.6432

58. Карпович О.Г.. Афганистан - 2014 во внешнеполитической стратегии США и Канады // Международные отношения. 2013. - № 4. - C. 104-107. DOI: 10.7256/2305-560Х.2013.4.7305

59. Карпович О.Г.. Демократия и демократизация в контексте нового миропорядка // Политика и Общество. - 2013. - № 8. С. 104-107. DOI: $10.7256 / 1812-8696.2013 .8 .9142$

60. Карпович О.Г.. Современные концепции и модели управления международными конфликтами (сравнительный политологический анализ) // Национальная безопасность / nota bene. - 2013. - № 4. - C. 104-107. DOI: 10.7256/2073-8560.2013.4.6434

61. Карпович О.Г.. Президентские выборы в США: демократия по-американски // Международные отношения. - 2013. - № 3. - С. 104-107. DOI: 10.7256/2305-560Х.2013.3.7093

62. Карпович О.Г.. Демократизация в современных концепциях российских и американских исследователей // Национальная безопасность / nota bene. - 2013. - № 3. - C. 104-107. DOI: 10.7256/2073-8560.2013.3.8083

63. О.Г. Карпович. Особенности позиций российских и американских экспертов по вопросам демократизации Ближнего Востока // Политика и Общество. - 2013. - № 5. - С. 104-107. DOI: 10.7256/1812-8696.2013.05.4

64. Карпович О.Г.. Международно-правовые основы миротворческой деятельности США // Международное право и международные организации / International Law and International Organizations. - 2013. - № 2. - C. 104-107. DOI: 10.7256/22266305.2013.2.8085

65. О. Г. Карпович. Современные подходы США и Европейского Союза к управлению международными конфликтами // Политика и Общество. - 2011. - № 12. - С. 104-107

\section{References (transliterated):}

1. Antsupov A. Ya, Shipilov A. I. Slovar' konfliktologa. SPb: Piter, 2006. - $517 \mathrm{~s}$.

2. Brodel' F. Grammatika tsivilizatsii. - M.: Izdatel'stvo «Ves' mir», 2008. - $552 \mathrm{~s}$.

3. Brodel' F. Material'naya tsivilizatsiya, ekonomika i kapitalizm. XV-XVIII vv. T. 1. Struktury povsednevnosti. Vozmozhnoe i nevozmozhnoe. - M.: Izdatel'stvo «Ves' mir», 2007. - 592 s.

4. Brodel' F. Material'naya tsivilizatsiya, ekonomika i kapitalizm. XV-XVIII vv. T. 2. Igry obmena. - M.: Izdatel'stvo «Ves' mir», 2006. $-672 \mathrm{~s}$.

5. Brodel' F. Material'naya tsivilizatsiya, ekonomika i kapitalizm. XV-XVIII vv. T. 3. Vremya mira. - M.: Izdatel'stvo «Ves’ mir», 2007. - 752 s. 
DOI: 10.7256/1811-9018.2014.11.12937

При цитировании этой статьи сноска на dоі обязательна

\section{Право и политика $11(179) \cdot 2014$}

6. Gerodot. Istoriya. - M.: AST: AST MOSKVA, 2006. - $696 \mathrm{~s}$.

7. Danilevskii N. Ya. Rossiya i Evropa. - M.: Kniga, 1991. - 574 s.

8. Ezhegodnik SIPRI 2011: vooruzheniya, razoruzhenie i mezhdunarodnaya bezopasnost'. - M.: IMEMO RAN, $2012 .-768$ s.

9. Inozemtsev V. L. Raskolotaya tsivilizatsiya. - M.: Nauka, Akademiya, 1999. - 704 s.

10. Kiselev S. G. Osnovnoi instinkt tsivilizatsii i geopoliticheskie vyzovy Rossii. - M.: Izvestiya, 2002. - 368 s.

11. Kuzyk B. N., Yakovets Yu. V. Tsivilizatsii: teoriya, istoriya, dialog, budushchee. V 2-kh t. T. 1. Teoriya i istoriya tsivilizatsii. - M.: Institut ekonomicheskikh strategii, 2006. - $768 \mathrm{~s}$.

12. Kuzyk B. N., Yakovets Yu. V. Tsivilizatsii: teoriya, istoriya, dialog, budushchee. V 2-kh t. T. 2. Budushchee tsivilizatsii i geotsivilizatsionnye izmereniya. - M.: Institut ekonomicheskikh strategii, 2006. - $648 \mathrm{~s}$.

13. Mak-Nil U. Voskhozhdenie Zapada. Istoriya chelovecheskogo soobshchestva. - M.: Nika-tsentr, Starklait, $2004 .-1064$ s.

14. Manoilo A. V. Tekhnologii nesilovogo razresheniya sovremennykh konfliktov. / Pod red. prof. A.I. Petrenko. - M.: Goryachaya liniya - Telekom, 2008. - $392 \mathrm{~s}$.

15. Morgan L. G. Drevnee obshchestvo ili Issledovanie linii chelovecheskogo progressa ot dikosti cherez varvarstvo k tsivilizatsii. - L.: Izd-vo in-ta narodov Severa TsIK SSSR, 1935. - $350 \mathrm{~s}$.

16. Leont'ev K. N. Slavyanofil'stvo i gryadushchie sud'by Rossii. - M.: Institut russkoi tsivilizatsii, 2010. - $1232 \mathrm{~s}$.

17. Polibii. Vseobshchaya istoriya. V 2 tomakh. Tom 1. Knigi I-X. - M.: OOO «Izdatel'stvo AST», 2004. - 765 s.

18. Polibii. Vseobshchaya istoriya. V 2 tomakh. Tom 2. Knigi XI-XXIX. - M.: OOO «Izdatel'stvo AST», $2004 .-765$ s.

19. Noimann I. Ispol'zovanie «Drugogo»: Obrazy Vostoka v formirovanii evropeiskikh identichnostei. - M., Dialog, $2004 .-316$ s.

20. Russo Zh. - Zh. Traktaty. - M.: Nauka, 1969. - 703 s.

21. Andrei Manoilo. "Revoluciones de los higos", elemento enfurecido o «caos controlado»? // Vida Internacional. Digest. 2011. pp. 148-162

22. Manoilo A.V. Natsional'no-gosudarstvennye modeli psikhologicheskogo upravleniya konfliktami. // Obozrevatel'-Observer. 2008. - №2. - S.118-123.

23. Sorokin P. A. Sotsial'naya i kul'turnaya dinamika. - M.: AST, Astrel', 2006. - $1176 \mathrm{~s}$.

24. Starobinskii Zh. Poeziya i znanie. Istoriya literatury i kul'tury. - M.: Yazyki slavyanskoi kul'tury, 2002. - 496 s.

25. Toinbi A. Dzh. Postizhenie istorii - M.: Progress, 1991. - 736 s.

26. Toinbi A. Tsivilizatsiya pered sudom istorii. - M.: Airis-Press.

27. Fevr L. Boi za istoriyu. - M.: Nauka, 1991. - $629 \mathrm{~s}$.

28. Fukidid. Istoriya. Tom I. - SPb.: Prolog, Nauka, 1994. - 403 s.

29. Fukidid. Istoriya. Tom II. - SPb.: Prolog, Nauka, 1994. - 445 s.

30. Chaadaev P. Ya. Izbrannye sochineniya i pis'ma. - M., Pravda, 1991. - $560 \mathrm{~s}$.

31. Khantington S. Stolknovenie tsivilizatsii. - M.: AST, 2005. - 576 s.

32. Shpengler O. Zakat Evropy. Ocherki morfologii mirovoi istorii. V 2-kh t. T. 1. Geshtal't i deistvitel'nost'. - M.: Mysl', 1998. - 663 s.

33. Avksent'ev V. A., Aksyumov B. A., Khots A. Yu. Konflikt tsivilizatsii: PRO ET CONRA // Sotsiologicheskie issledovaniya 2000, № 3. S. $73-81$

34. 37. Abgadzhava D. A., Filatova N. V. O vozmozhnostyakh regulirovaniya sotsial'no-politicheskikh konfliktov // Gumanitarnye issledovaniya, 2007. № 4. S. 17-19

35. Avksent'ev V. A., Aksyumov B. V. «Konflikt tsivilizatsii» v regional'nom prelomlenii: Kavkaz i Balkany // Polis (Politicheskie issledovaniya). 2007. № 4. - S. 146-157.

36. Komleva N. A. Geopoliticheskoe szhatie // Mirovaya ekonomika i mezhdunarodnye otnosheniya. 2003. № 2. S. 66-75Fukuyama F. Konets istorii?// SShA: ekonomika, politika, ideologiya. 1990. № 5. S. 39-54.

37. Trifonov S. S. Konstruirovanie identichnosti kak geopoliticheskaya tekhnologiya // Sovremennye problemy sotsio-gumanitarnogo znaniya // Materialy XVI Mezhdunarodnoi konferentsii «Baltiiskii forum», 4-6 dekabrya 2013 g. / Pod red. Ivashkin N., Antonov B., Peshekhodina A., SPb., Izd-vo SPbGUT im. Bonch-Bruevicha, 2013. - $212 \mathrm{~s}$.

38. Belov V. I. Klassifikatsiya konfliktov // http://www.sociology.mephi.ru/docs/sociologia/html/belov_conflicts.html

39. Manoilo A. Nesilovoe regulirovanie mezhdunarodnykh konfliktov. Kul'turno-tsivilizatsionnye paradigmy //http://www.perspektivy.info/book/nesilovoje_regulirovanije_mezhdunarodnyh_konfliktov_kulturno-civilizacionnyje_paradigmy_2009-03-30.htm

40. Manoilo A. Politicheskie konflikty v mezhdunarodnykh otnosheniyakh i mirovoi politike // http://mir-politika.ru/3999-politicheskiekonflikty-v-mezhdunarodnyh-otnosheniyah-i-mirovoy-politike.html

41. Sheptalova E. G. Psikhologiya konflikta // http://www.personalpsychology.ua/Sheptalova/articles/357/sense.html

42. Ferguson A. An Essay on the History of Civil Society // http://oll.libertyfund.org/title/1428

43. Manoilo A.V. Model' informatsionno-psikhologicheskoi operatsii v mezhdunarodnykh konfliktakh. // Pravo i politika. - 2008. - №6. - S.1387-1394.

44. Rep'eva A.M. Natsiestroitel'stvo. Formirovanie i sushchnostnye kharakteristiki (SShA i Rossiya).// NB: Mezhdunarodnye otnosheniya. 2013. № 2. S. 68-79.

45. O. G. Karpovich Sravnitel'nyi analiz formatov modelei i tekhnologii upravleniya mezhdunarodnymi konfliktami SShA i ES i sovremennykh mirotvorcheskikh operatsii // Natsional'naya bezopasnost' / nota bene. - 2011. - 6. - C. 138-149.

46. O. G. Karpovich Mirotvorcheskaya deyatel'nost' SShA i anglosaksonskie tekhnologii upravleniya mezhdunarodnymi konfliktami // Natsional'naya bezopasnost' / nota bene. - 2012. - 1. - C. 64-74.

47. I. V. Bocharnikov Severo-Kavkazskii region: problemy i perspektivy realizatsii gosudarstvennoi politiki Rossii // Mezhdunarodnye otnosheniya. -2012 . - 1. - C. 36-45. 
48. A. V. Manoilo Paradigmy upravleniya mezhdunarodnym konfliktami: konkurentsiya ili konfrontatsiya // Natsional'naya bezopasnost' / nota bene. - 2011. - 5. - C. 135-142.

49. Petrenko A.I. Siriiskii gambit // Mezhdunarodnye otnosheniya. - 2013. - 1. - C. 92-95. DOI: 10.7256/2305-560X.2013.01.11.

50. Gusher A.I. Geopoliticheskaya kartina sovremennogo mira // Mezhdunarodnye otnosheniya. - 2013. - 1. - C. 13-21. DOI: 10.7256/2305-560X.2013.01.2.

51. A. V. Manoilo Aktual'nye voprosy modernizatsii sovremennoi kul'turno-tsivilizatsionnoi teorii upravleniya mezhdunarodnymi konfliktami // Natsional'naya bezopasnost' / nota bene. - 2011. - 4. - C. 60-66.

52. Karpovich O.G.. Novyi miroporyadok i konfigurirovanie sistemy mezhdunarodnykh otnoshenii vo vneshnei politike SShA // Politika i Obshchestvo. - 2013. - № 10. - S. 104-107. DOI: 10.7256/1812-8696.2013.10.10013

53. Karpovich O.G.. Problemy i perspektivy issledovaniya sovremennykh kontseptsii, modelei i tekhnologii upravleniya mezhdunarodnymi konfliktami // Natsional'naya bezopasnost' / nota bene. - 2013. - № 5. - S. 104-107. DOI: 10.7256/2073-8560.2013.5.6432

54. Karpovich O.G.. Afganistan - 2014 vo vneshnepoliticheskoi strategii SShA i Kanady // Mezhdunarodnye otnosheniya. - 2013. № 4. - S. 104-107. DOI: 10.7256/2305-560X.2013.4.7305

55. Karpovich O.G.. Demokratiya i demokratizatsiya v kontekste novogo miroporyadka // Politika i Obshchestvo. - 2013. - № 8. - S. 104-107. DOI: 10.7256/1812-8696.2013.8.9142

56. Karpovich O.G.. Sovremennye kontseptsii i modeli upravleniya mezhdunarodnymi konfliktami (sravnitel'nyi politologicheskii analiz) // Natsional'naya bezopasnost' / nota bene. - 2013. - № 4. - S. 104-107. DOI: 10.7256/2073-8560.2013.4.6434

57. Karpovich O.G.. Prezidentskie vybory v SShA: demokratiya po-amerikanski // Mezhdunarodnye otnosheniya. - 2013. № 3. - S. 104-107. DOI: 10.7256/2305-560X.2013.3.7093

58. Karpovich O.G.. Demokratizatsiya v sovremennykh kontseptsiyakh rossiiskikh i amerikanskikh issledovatelei // Natsional'naya bezopasnost' / nota bene. - 2013. - № 3. - S. 104-107. DOI: 10.7256/2073-8560.2013.3.8083

59. O.G. Karpovich. Osobennosti pozitsii rossiiskikh i amerikanskikh ekspertov po voprosam demokratizatsii Blizhnego Vostoka // Politika i Obshchestvo. - 2013. - № 5. - S. 104-107. DOI: 10.7256/1812-8696.2013.05.4

60. Karpovich O.G.. Mezhdunarodno-pravovye osnovy mirotvorcheskoi deyatel'nosti SShA // Mezhdunarodnoe pravo i mezhdunarodnye organizatsii / International Law and International Organizations. - 2013. - № 2. - S. 104-107. DOI: 10.7256/22266305.2013.2.8085

61. O. G. Karpovich. Sovremennye podkhody SShA i Evropeiskogo Soyuza k upravleniyu mezhdunarodnymi konfliktami // Politika i Obshchestvo. - 2011. - № 12. - S. 104-107 